\title{
The Eurozone Crisis and the Structured Grexit as the Proper Alternative for Greece
}

\author{
Theodore Katsanevas ${ }^{1}$
}

\begin{abstract}
:
In our paper we argue that, the economic stagnation of only the euro zone countries in a world that is growing much faster, is mainly due to the overvalued euro and the related austerity policy measures imposed under Berlin guidelines, The malpractices of the international markets, the underground currency wars between the dollar, the euro and the yen, are also to blame. The imposition of the euro zone as an optical currency area in totally different economies and without a fair political umbrella has been wrong. For Greece, it has been catastrophic. Between 2010-2014, the country's average annual GDP, declined at a yearly level of 4,6\% and there are no signs that this will soon be reversed. The strict austerity policies imposed by the new "Memorandum", will lead to more recession. In front of the deadlock, a structured Grexit is the proper alternative solution. This implies a controlled bankruptcy, suspension of debt payments and negotiations for cutting and extending its repayment period.
\end{abstract}

During the initial negotiation days, the government must provide liquidity to the economy through the issuing of non-interest state bonds at a ratio of $1: 1$ in relation to the euro. Existing capital controls and transactions with electronic money will be helpful for the same cause. The next step is the issuing of the new drachma devaluated at 25-30\%. In order to avoid hyperinflation, the amount of the new drachma produced, must not exceed a certain level of the M2. The euro may continue to be used as a parallel currency for a period decided in accordance with the result of negotiations and economic trends. Low and medium incomes could be increased gradually, in relation with labour productivity and GDP growth trends. Government spending restrictions, the combat of corruption, impunity, bureaucracy, tax evasion and the strengthening of productive investments, are also necessary for a healthy new beginning.

Key Words: Greek Tragedy, stagnation, overvalued euro, austerity policies, currency wars

\footnotetext{
${ }^{1}$ Paper presented at the International Conference of Applied Business and Economics (ICABE), headed by prof. Eleftherios Thalassinos by Theodore Katsanevas Ph.D.( L.S.E.), M.A. (Warwick), Emeritus Professor of the University of Piraeus. For help provided in this article, I would like to thank the assistant professor of Stanford University Andreas Katsanevas and my research assistant and economist Olga Zagoreou
} 


\section{The Modern Greek Tragedy}

Greece is now leaving behind the seventh consecutive year of deep recession after its entrance to the euro zone in January 2002. Although this entrance was supposed to be for the country's benefit, the absolute opposite occurred. Before 2002, the country functioned relatively well with the drachma; it never experienced a Modern Greek Tragedy like today. Ever since the world war II, the Greek GDP grew at a satisfactory pace in relation to similar trends in other developed countries (Histograms 1 and 2). Even if we accept that, part of the blame for the present economic deadlock is due to the viciousness of the Greek political system, we must not forget that, the same political system, more or less, existed also in the past during the drachma years. Moreover in the same declivity trend, although to a lesser extend, Greece is followed by Italy, Portugal, Spain, Ireland and lately by Cyprus. But the whole euro zone is not doing well also, as we will see below here ${ }^{2}$.

Histogram 1. GDP growth of Greece, United Kingdom, France, Germany, USA between the years 1951-1979

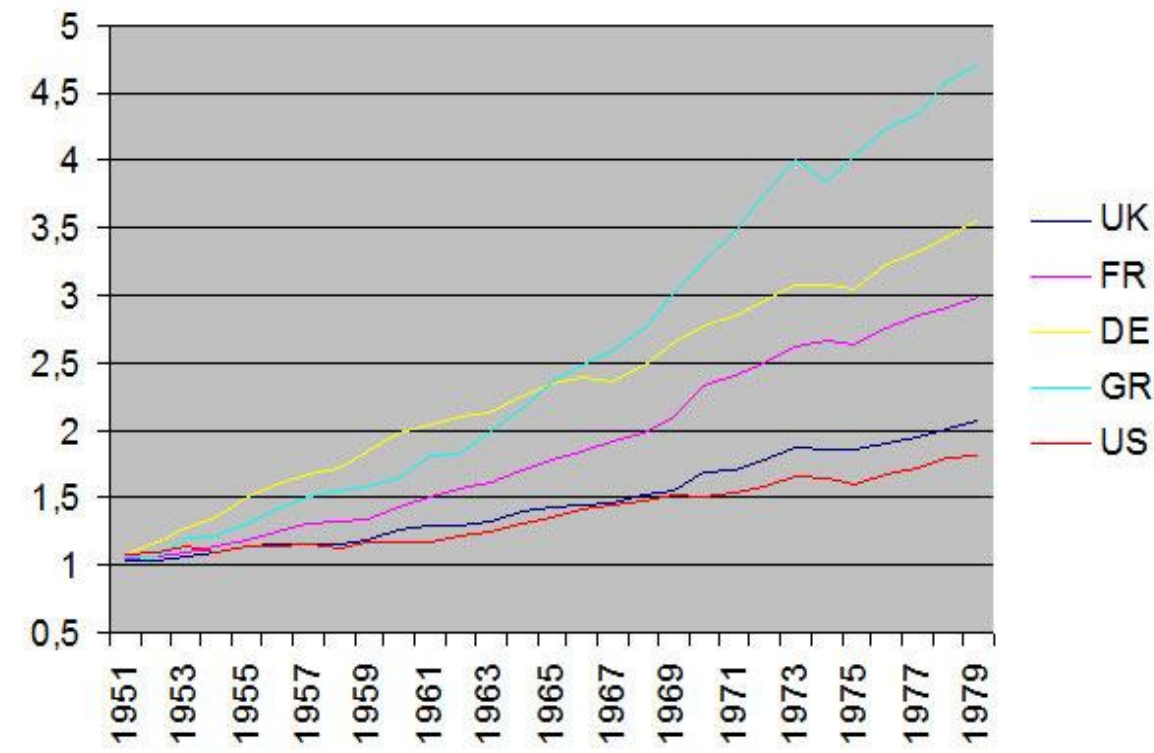

\footnotetext{
${ }^{2}$ The EU consists of 28 member countries countries and the euro zone of 19 countries noted by bold letters in the following list, where the first number indicates the year of entrance to the E.U. and the second, where it applies, the year of entrance to the eurozone: Austria $(1995,1999)$, Belgium, 1958, 1999, Bulgaria, 2007, Croatia, 2013, Cyprus, 2004, 2008, Czech Republic, 2004, Denmark, 1973, Estonia, 2004, 2011, Finland, 1995, 1999, France, 1958, 1999, Germany 1958, 1999, Greece, 1981, 002 Hungary, 2004, Ireland, 1973, 1999, Italy, 1958, 1999, Latvia, 2004, 2014, Lithuania, 2004, 2015, Luxembourg, 1958, 1999, Malta, 2004, 2008, The Netherlands, 1958, 1999, Poland, 2004, Portugal, 1986, 1999, Romania, 2007 Slovakia, 2004, 2009 Slovenia, 2004, 2007, Spain, 1986, 1999

Sweden, 1995, United Kingdom, 1973
} 
Histogram 2. GDP growth of Greece, United Kingdom, France, Germany, USA between the years 1981-1999

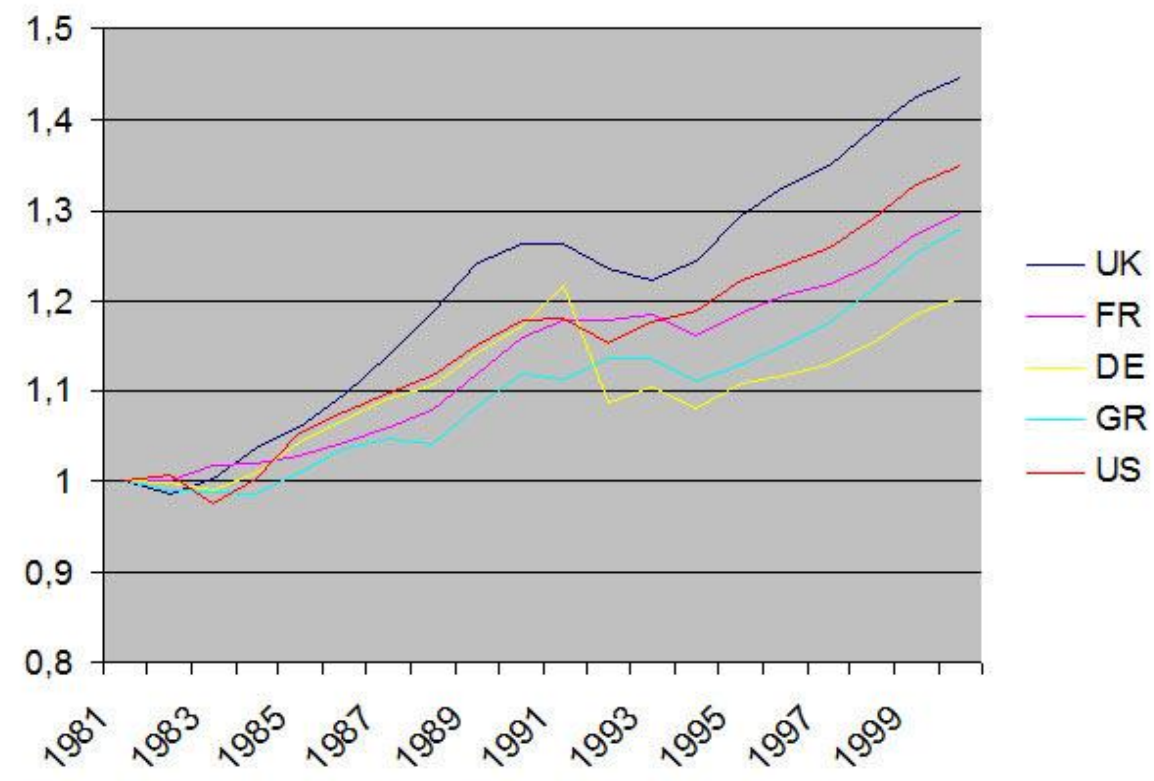

\section{Source: The Pen World Tables}

Since 2008, the Greek GDP dropped to more than $27 \%$ and this dramatic fall has no parallel in modern times (Histogram 3). During the same period, the country's Stock Market lost more than 55\% of its value. Official uunemployment climbed to 25-26\% and over $50 \%$ for the young. The risk of poverty for people aged 18-64 years is estimated at 45.8\%. (ELSTAT 2015). Hundreds of thousands of desperate people, mainly young, are fleeing abroad in search for a job. Despite extreme austerity measures and the haircut of 2011 (PSI) ${ }^{3}$, mainly financed by Greek pension funds, state and local organizations, Universities and private bondholders (Bevan, 2012), the debt continues to rise. From $€ 303.5$ billion or $157 \%$ of the GDP in 2012, it soared to $€ 328$ billion or about $188,9 \%$ of the GDP by the end 2014. And according to IMF recent forecasts, it will jump to $196,9 \%$ in 2015 and to $206,6 \%$ in 2016 . As shown in Histogram 4, the debt as a percentage of the GDP, grew impressively after the year 2008. From the same Histogram 4, the widely said hypothesis that, the heavy Greek debt is basically inherited from the past and especially from the $80 \mathrm{~s}$, is

\footnotetext{
${ }^{3}$ The euro zone countries in their session of 21/8/2011, decided the implementation in Greece of the so-called Private Sector Involvement (P.S.I ), which implies payments for the public debt with inflows from the private sector ( bonds belonging to Social Security and Public Organizations, Local Government, Universities, private bondholders etc). The term PSI has been firstly used for the restructuring of the public debts of Russia, Turkey, Argentina, Ecuador, Brazil.
} 
proven to be a big myth. It is evident that the debt made a big jamb after the year 2008.

Histogram 3. GDP growth 2008-2014, Greece, Germany, Spain, Portugal, Italy, Ireland

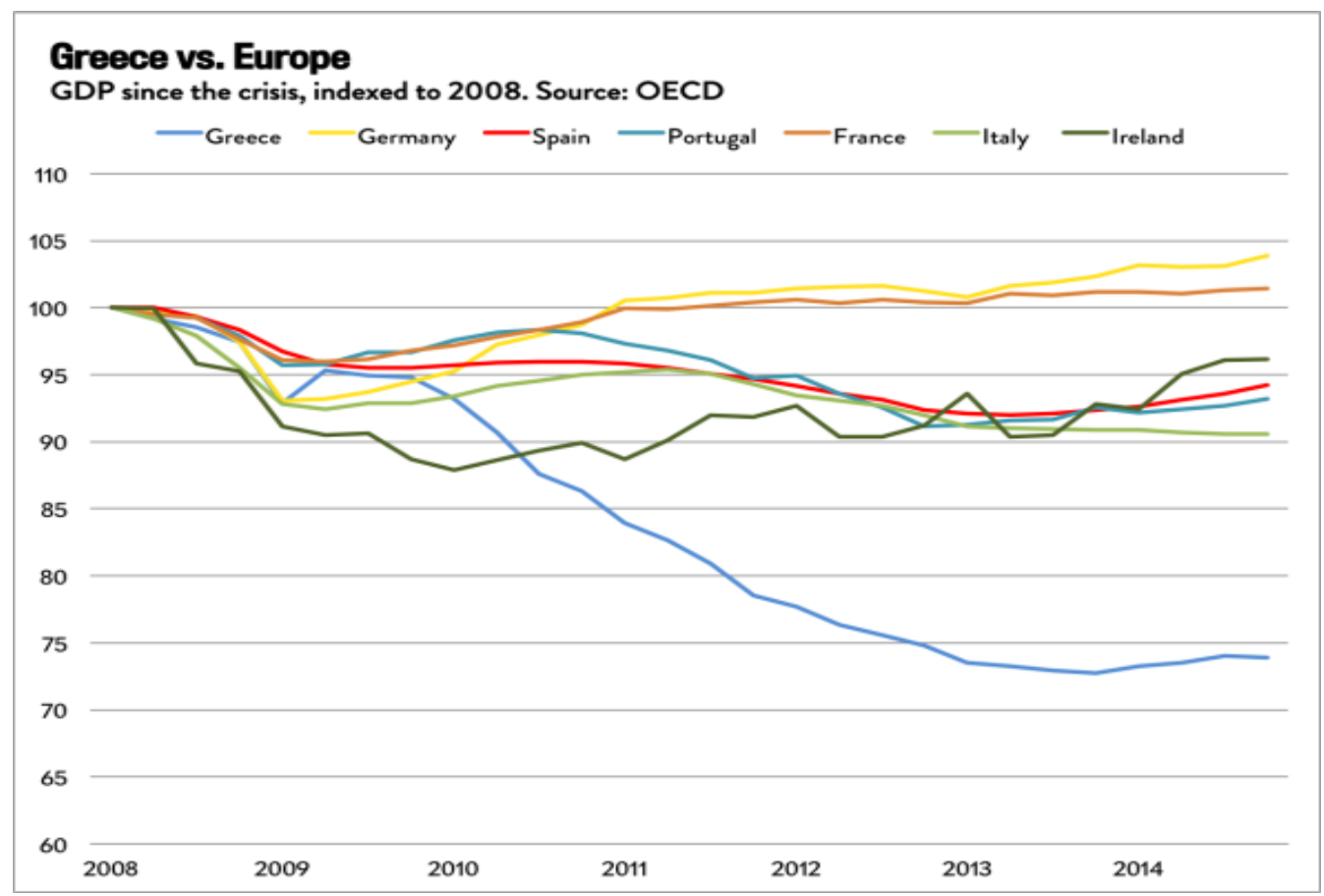

Moreover, the debts of private loans are also increasing dramatically. More than one in two businesses fail to service their loans, tax and insurance obligations. Overall arrears to the IRS are growing sharply and projected to surpass 100 billion by the end of 2015. More than half of thetotal of 5.8 million taxpayers owe to the IRS. Continuously expanding is the number of uninsured citizens and entrepreneurs. The pension funds, wounded with the haircut of their reserves from the PSI in 2011, are sinking (Bevan 2012). Their deficits are growing sharply and this results to huge cuts in all kind of pensions. The economy is drying up and inflation moves with a negative sign of $-1,4 \%$ in 2014 and of $0,5 \%$ in 2015( Ministry of the Economy, Budget Draft 2016) and this, creates conditions of permanent recession. In general, most indicators of the economy (GDP, unemployment, inflation, balance of payments, investments, industrial production, construction, etc), move with a monotonous downward trend (The World Bank Factbook, 2015, IMF Economic Outlook,2015, ELSTAT). 
Histogram 4. Evolution of the Greek debt as a percentage of the GDP, 1970-2016

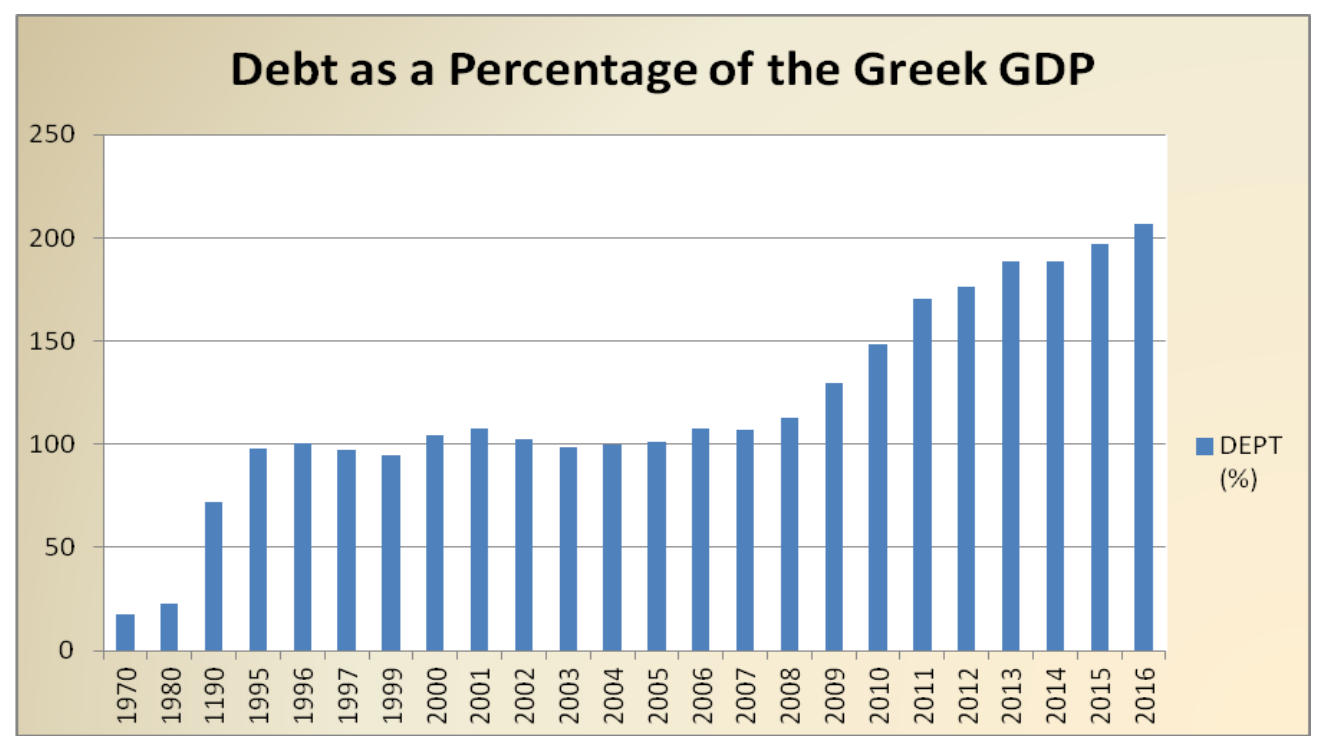

Source: Histograme based on data of Eurostat and the European Comission

Histogram 5. GDP forecasts according to the $1^{\text {st }}$ and the $2^{\text {nd }}$ programmed and actual results

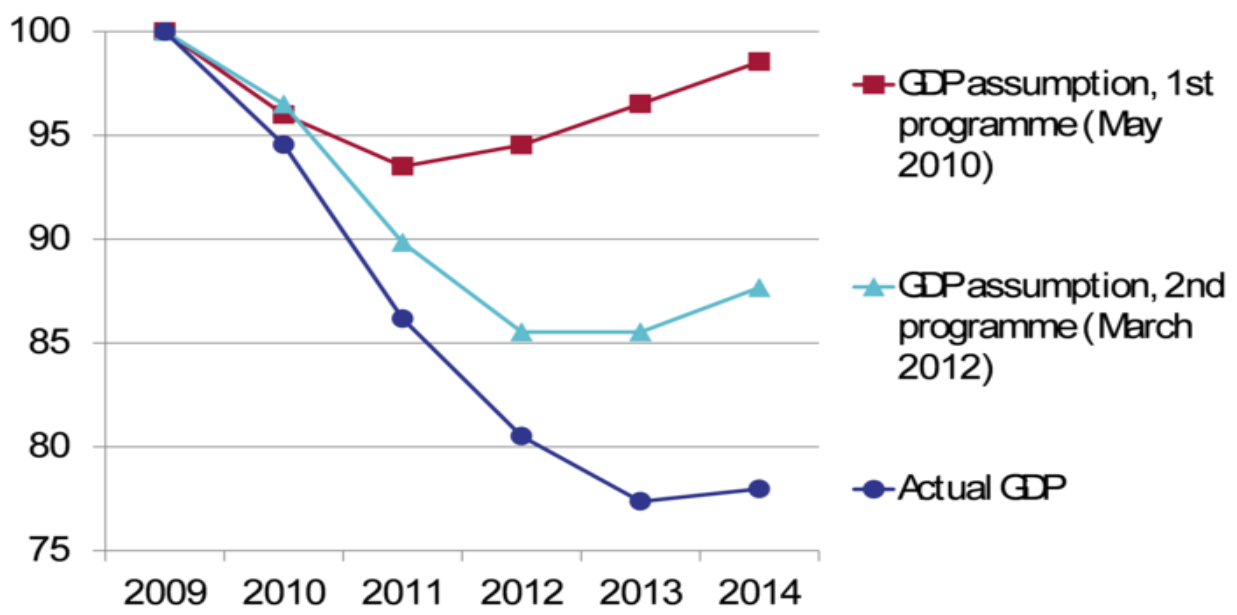

Source: Bruegel, Darvas (2015), Chionis ( 2015)

Every year, the Greek government, the European Commission, the IMF, announce optimistic forecasts for the future trends of the Greek economy. These forecasts, also called by government officials as "the success story", are always refuted in the end. The IMF accepted that it was wrong with its initial predictions concerning mainly the country's multiplier (I.M.F., 2013, Spiegel \& Harding, 2013, Blanchard, 2015). 
Yet, the lesson was not learned. New even more extreme austerity policies, the so called "Third Memorandum" have been agreed in July 2015, under the notion that there is no alternative (TINA) ${ }^{4}$. This is applied currently, at a time when the total economic turnover is declining sharply with no real hopes for a strong adverse course. Structural reforms implied with the present strict monetary and austerity policies, create deep human pain but not important economic gains ${ }^{5}$. As proven by a special OECD study, overall potential GDP gain from undertaking the full range of structural reforms, might come close to $10 \%$ at a 10 -year horizon, or $1 \%$ per year (Bouis and Duval 2011). Under these circumstances, there is no hope that the country will manage to get out of the deep recession trap. At least $10 \%$ of the Greek GDP per year is necessary for payments of the country's enormous debt. (Nikas, 2015) ${ }^{6}$ Moreover, in accordance with the Okun's law, there is a need of at least 2,5\% GDP growth per year, so as to reduce unemployment at 1\%. (Okum, 1965 and $1972)^{7}$. Therefore, in order to enter into a phase of employment stabilization and growth, an overall annual GDP of over $12 \%$ is needed. The chance for this to happen in the visible future is something like a science fiction scenario. The Modern Greek Tragedy has no end.

The extreme recession policies, the huge levels of unemployment, the excessive compression of labour rewards and of pensions, are both inhumane and uneconomic. They lead to a large drop of domestic demand and to social uprising, with dangerous economic and social consequences. Recession creates more recession lowers the business circle and the tax base. Poverty creates more poverty, misery, hate and upheaval. Loans lead to more loans and dependency - a perpetual cycle ${ }^{8}$. Mainly due to the overvalued euro, the lack of currency liquidity and the high interest rates of loans for business transactions, the country's poor competitiveness is dying. Recession cannot be beaten with more recession policies, an overvalued currency and without a generous development plan (Krugman, 2012). Over the long term, this is burdensome to all, even for Greece's lenders. These policies are totally wrong. They are not the outcome of logic. And common logic is what we need today.

\footnotetext{
${ }^{4}$ The famous slogan "There is no alternative" (TINA), was used by Margaret Thatcher to imply that, despite capitalism's problems, "there is no alternative" to it as an economic system, and that neoliberalism must push back against socialism. The phrase became something of a rallying statement in favourur of free markets, free trade, and capitalist globalization, with Thatcher and her followers believing that it is the only way which modern societies can advance themselves.

5 Dani Rodrik (2015b) briefly describes structural reforms as improvements in regulation and institutions to enhance efficiency with which markets operate, reducing transaction costs of market activity,product and service markets: licensing fees and other costs, labour markets: hiring/firing costs, reducing entry barriers, eliminating monopolies,enhancing role of private sector over government, improved public sector administration, e.g., tax collection, rule of law

${ }^{6}$ Angela Merkel in August 2015 said that there is a need of $15 \%$ of the Greek GDP per year for the country's debt obligations. Yet, 10\% has been accepted for the same cause for the period until 2022.

${ }^{7}$ The Okun's Law, generally acceptable by forecasters as a tool for short-run trend analysis, notes that, a real GDP growth of 2-3\% results to $1 \%$ decline in the rate of cyclical unemployment.

${ }^{8}$ Menandros an ancient Greek philosopher has said that ,"loans make slaves the human beings".
} 


\section{Greece and the euro zone at the bottom of the world growth}

On the basis of the GDP growth, the euro zone stands today at the bottom of the world economic trends. This is shown outstandingly by the Histogram 6 presented here and more analytically, in table 1, both based on own elaboration of World Bank data (The Global Outlook, 2015). Between 2010-2014, the Greek economy witnessed an average annual GDP decline of $-4,6 \%$. This misery road was followed by the so-called GIPSI countries (Greece, Italy, Portugal, Spain, Ireland), their annual average decline standing at $-1,06 \%$ during the same years. The annual average growth of all the euro zone countries was only $0,63 \%$, of the non-euro zone countries was $1,27 \%$ and of the E.U. on the whole, $1,01 \%$. Even Germany, the economic engine and political leader of the euro zone, shows a poor average GDP growth of $1,68 \%$, during the same period. Also disappointing are the cases of the Netherlands $(0,28 \%)$, Finland (0,56\%), France (1,04\%), Belgium ( $1,12 \%)$ Austria $(1,28 \%)$.

During these five years that we study here (2010-2014), the average annual growth of all countries internationally including the E.U., was 3,62\% and of all the countries internationally, with the exception of the euro zone, was $4,09 \%$. Such a growth gap will be continued in the near future, as valid forecasts indicate and are presented in Table 2 here. It is more than evident that, the euro zone and especially the GIPSI, follow and will follow, a misery queue in the global economic growth race. What are the basic reasons for such a crucial finding that is a crucial question?

Histogram 6. Average Annual Growth of GDP in Greece, the GIPSI, the euro zone and the rest of the world

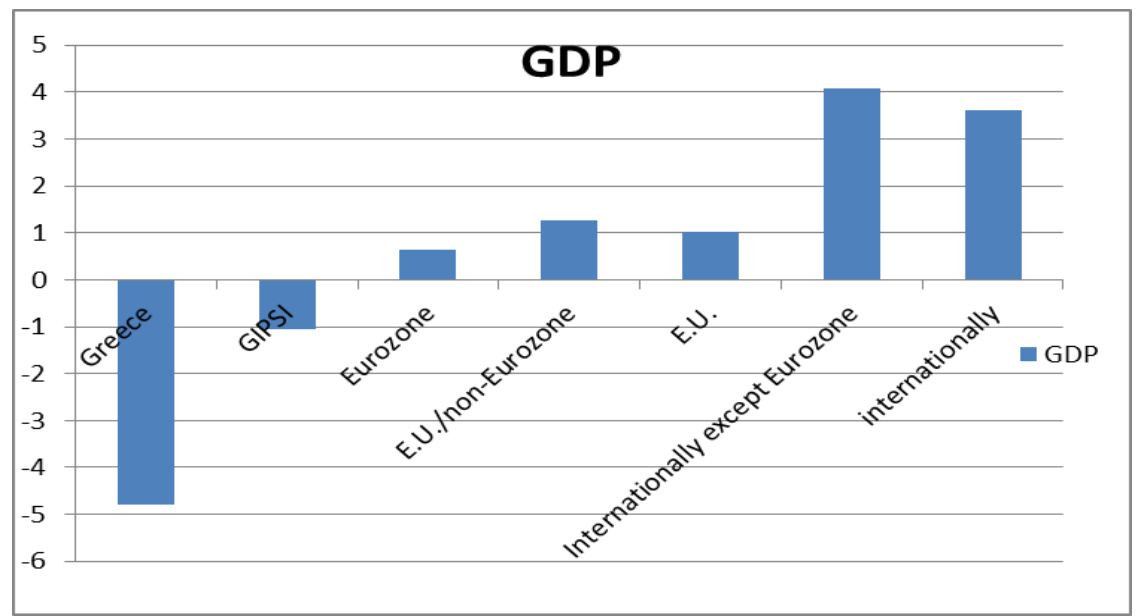

Source: World Bank, The Global Outlook, 2015. Author's elaboration of analytical data of all countries internationally. Latvia and Lithuania have not been included in the above calculations as euro zone countries, because they entered in the euro area in 2014 and 2015 respectively. The so-called GIPSI are Greece, Italy, Portugal, Spain and Ireland. 
Most of the faster growing countries, enforce an economic strategy that inherits controlled currency devaluations. They follow the Chinese example of implementing soft monetary policies, in the light of the existence of an underground currency wars in present times (Richards 2012, Rousseff 2011), mainly between the dollar, the euro and the yen.

Table 1. Average annual growth of all world countries between 2010 - 2014

\begin{tabular}{|l|l|}
\hline COUNTRIES & GDP Growth \\
\hline & NEGATIVE GROWTH \\
\hline Central African Republic/ Greece & $-4,92 /-4,8$ \\
\hline Bermuda/ Andorra/ Barbados & $-3,175 /-3 /-2,8$ \\
\hline Puerto Rico/ Cyprus/ Yemen, Rep./ Croatia & $-1,975 /-1,68 /-1,275 /-1,1$ \\
\hline Portugal/ St. Lucia/ Italy/ Spain & $-0,92 /-0,68 /-0,52 /-0,5$ \\
\hline $\begin{array}{l}\text { Antigua and Barbuda/ St. Vincent and the } \\
\text { Grenadines/ Equatorial Guinea }\end{array}$ & $-0,36 /-0,28 /-0,2$ \\
\hline & $\begin{array}{l}\text { GROWTH BETWEEN 0- } \\
\mathbf{2 \%}\end{array}$ \\
\hline $\begin{array}{l}\text { Slovenia/ Dominica/ Micronesia, Fed. Sts./ The } \\
\text { Netherlands }\end{array}$ & $0,16 / 0,22 / 0,25 / 0,28$ \\
\hline Serbia/ Trinidad and Tobago & $0,36 / 0,425$ \\
\hline Denmark/ Jamaica/ Finland/ Ukraine & $0,54 / 0,55 / 0,56 / 0,56$ \\
\hline Grenada/ Iran, Islamic Rep. & $0,6 / 0,7$ \\
\hline $\begin{array}{l}\text { South Sudan/ Bosnia and Herzegovina/ Czech } \\
\text { Republic }\end{array}$ & $0,82 / 0,84 / 0,96$ \\
\hline France/ Bahamas, & $1,04 / 1,06$ \\
\hline Belgium/ Venezuela, RB/ Sudan & $1,12 / 1,12 / 1,14$ \\
\hline Bulgaria/ Samoa/ Iceland/ Hungary/ Austria & $1,2 / 1,2 / 1,22 / 1,24 / 1,28$ \\
\hline Romania/ Ireland/ Norway/ St. Kitts and Nevis & $1,42 / 1,44 / 1,44 / 1,48$ \\
\hline Japan/ Montenegro/ Vanuatu & $1,5 / 1,6 / 1,65$ \\
\hline United Kingdom/ Tuvalu/El Salvador & $1,7 / 1,825 / 1,84$ \\
\hline Switzerland/ Germany/ Haiti/ Libya & $1,95 / 1,96 / 1,96 / 1,96$ \\
\hline & $\begin{array}{l}\text { GROWTH BETWEEN 2- } \\
\mathbf{4 \%}\end{array}$ \\
\hline $\begin{array}{l}\text { Tonga/ Madagascar/ Cabo Verde/ New Zealand/ } \\
\text { Brunei Darussalam }\end{array}$ & $2,024 / 2,04 / 2,06 / 2,075 / 2,08$ \\
\hline $\begin{array}{l}\text { Honduras/ Kiribati/ United States/ Albania/ } \\
\text { Swaziland }\end{array}$ & $2,12 / 2,2 / 2,2 / 2,22 / 2,24$ \\
\hline Guinea/ FYROM/ Luxembourg & $2,34 / 2,34 / 2,375$ \\
\hline Sweden/ South Africa/ Malta/ Tunisia & $2,4 / 2,42 / 2,425 / 2,475$ \\
\hline
\end{tabular}




\begin{tabular}{|l|l|} 
Gambia, / Canada/ Slovak Republic & $2,54 / 2,56 / 2,58$ \\
\hline Australia/ Belize/ Egypt, Jordan/ Latvia/ Cuba & $2,6 / 2,675 / 2,68,2,7 / 2,7 / 2,7,25$ \\
\hline Guinea-Bissau/ Russian Federation/ Comoros/ Fiji & $2,8 / 2,82 / 2,86 / 2,96$ \\
\hline $\begin{array}{l}\text { Azerbaijan/ Lebanon/ Poland/ Brazil/ Algeria/ } \\
\text { Mexico }\end{array}$ & $3 / 3,02 / 3,08 / 3,22 / 3,32 / 3,32$ \\
\hline Marshall Islands/ Senegal/ Mali & $3,45 / 3,46 / 3,48$ \\
\hline Belarus/ Pakistan/ Lithuania & $3,52 / 3,52 / 3,54$ \\
\hline Guatemala/ Mauritius/ Morocco/ Oman & $3,6 / 3,6 / 3,66 / 3,675$ \\
\hline $\begin{array}{l}\text { Korea, Rep./ Hong Kong SAR, China/ West Bank } \\
\text { and Gaza }\end{array}$ & $3,74 / 3,78 / 3,78$ \\
\hline Israel/ Kuwait/ Estonia, Bahrain/ Kyrgyz Republic & $3,8 / 3,825 / 3,84,3,96 / 3,98$ \\
\hline & $\mathbf{G R O W T H ~ B E T W E E N ~} \mathbf{4 -}$ \\
\hline United Arab Emirates/ Suriname/ Palau/ Eritrea & $4 / 4,1 / 4,14 / 4,18$ \\
\hline $\begin{array}{l}\text { Armenia/ Burundi/ Costa Rica/ Sao Tome and } \\
\text { Principe }\end{array}$ & $4,2 / 4,26 / 4,32 / 4,32$ \\
\hline Argentina/ Benin/ Nepal & $4,42 / 4,46 / 4,48$ \\
\hline Angola/ Chile/ Djibouti & $4,64 / 4,64 / 4,68$ \\
\hline Cameroon/ Lesotho/ Guyana/ Malawi/ Nicaragua & $4,7 / 4,7 / 4,72 / 4,72 / 4,74$ \\
\hline Colombia/ Thailand/ Uruguay & $4,82 / 4,84 / 4,98$ \\
\hline Ecuador/ Dominican Republic/ Congo, Rep. & $5 / 5,16 / 5,18$ \\
\hline Namibia/ Togo/ Saudi Arabia & $5,2 / 5,202 / 5,28$ \\
\hline Cote d'Ivoire/ Bolivia/ Moldova & $5,3 / 5,34 / 5,36$ \\
\hline Uganda/ Turkey/ Mauritania/ Georgia & $5,42 / 5,44 / 5,46 / 5,56$ \\
\hline Nigeria/ Gabon/ Malaysia & $5,74 / 5,76 / 5,78$ \\
\hline $\begin{array}{l}\text { Indonesia/ Solomon Islands/ Peru/ Seychelles/ } \\
\text { Vietnam }\end{array}$ & $5,8 / 5,8 / 5,84 / 5,84 / 5,84$ \\
\hline & $\mathbf{G R O W T H ~ B E T W E E N ~ 6 - 8}$ \\
\hline Kazakhstan/ Kenya/ Iraq & $6,02 / 6,02 / 6,06$ \\
\hline Bangladesh/ Philippines/ Liberia & $6,14 / 6,28 / 6,3$ \\
\hline Burkina Faso/ Singapore/ Afghanistan & $6,42 / 6,42 / 6,56$ \\
\hline Bhutan/ Botswana/ Tanzania/ Niger & $6,6 / 6,62 / 6,7 / 6,8$ \\
\hline Cambodia/ Maldives/ Paraguay & $6,96 / 6,96 / 6,96$ \\
\hline Tajikistan/ Chad/ Rwanda & $7,1 / 7,12 / 7,14$ \\
\hline Mozambique/ Zambia/ India & $7,2 / 7,2 / 7,26$ \\
\hline Sri Lanka/ Congo, Dem. Rep. & $7,42 / 7,74$ \\
\hline & $\mathbf{G R O W T H ~ B E T W E E N ~ 8 - ~}$ \\
\hline $\mathbf{1 0 \%}$ \\
\hline
\end{tabular}




\begin{tabular}{|l|l|} 
Papua New Guinea/ Lao PDR/ Uzbekistan & $8 / 8,1 / 8,22$ \\
\hline Panama/ Zimbabwe/ Myanmar & $8,3 / 8,32 / 8,35$ \\
\hline Ghana/ China/ Timor-Leste , Qatar & $8,54 / 8,6 / 8,68,9,66$ \\
\hline Ethiopia/ Sierra Leone & $\begin{array}{l}\text { GROWTH FROM 10\% \& } \\
\text { MORE }\end{array}$ \\
\hline Mongolia/ Turkmenistan, Macao SAR, China & $10,56 / 10,72$ \\
\hline
\end{tabular}

Source: Data from World Bank, The Global Outlook, 2015

Note: Euro zone countries, E.U.not euro zone countries

The USA, Japan, Switzerland, India, Russia, Brazil, Mexico, Island, Turkey, Ethiopia, South Africa, Nigeria, and almost all developing countries in different time and ways, have devalued their currencies in order to gain competitiveness, improve exports and decrease trade deficits. Argentina has posted impressive rates of economic growth after the uncoupling of the pesos from the US dollar and its devaluation in January 2002 (Cohen, 2011). In Japan, South Korea and China, it is noted that, "the skilful use of protective tariffs, currency manipulation, and government ownership and subsidies has produced economic miracles". (Rodrik, 2013).These facts and not only, suggest that despite leaving the 'security' of a fixed exchange rate, the economy can recover after abolishing a currency union.

It is argued that, a nation's exchange rate is the single most important price in its economy; it will influence the entire range of individual prices, imports and exports, and even the level of economic activity (Volcker and Gyohtten 1993). In the underground currency wars of the present days, Greece has surrendered its ability for currency control to Berlin, whose main concern is the strengthening of the euro, in an effort to verify the German economic and political supremacy. Yet, Germany and it's nearby euro zone countries are also not doing very well in terms of economic growth, as shown above. It may be argued that, the virus of stagnation from the south invades the north. Or is it the euro in itself, a basic cause of the illness?

\section{Blame the euro and not only}

The euro maybe was an impressive idea in theory as an optimal currency area (Mundell 1961), but in real life, it has been a heavy burden. Nowadays, seven years after the beginning of the crisis, the majority of the developed and developing world has gotten back on their feet. Only the euro zone stagnates and it will continue to do so as indicated above. A basic question arises: why is this happening?

According to our view, this is mainly due to the overvalued euro without the existence of a fair political umbrella, in combination with and the strict monetarist and austerity policies imposed by Berlin. The malpractices of the non controlled international markets, the existence of tax paradises, are also to blame for the world economic crises that have a stronger effect upon weak economies such as that of 
42

Greece. In an indirect way, the latter also pays the price of the underground currency war between the dollar, the euro and the yen. The overvalued euro in particular, puts a heavy burden upon the country's economic competitiveness. It is a costume that does not fit the Greek economy, which is mainly based on tourism that requires a labour-intensive production process. Labour costs can not be compressed below a certain level, so that the total production costs will be lower or equal to that of our competitors in the Balkans and the Mediterranean Sea. Accusations that the Greeks do not work hard are a myth. Working hours in Greece are the highest in Europe as shown in the Histogram 7. Yet, the country's international competitiveness is law and this is due to other reasons as we try to prove here.

The deadlocks of the painful agreement for the third memorandum will soon be seen in the upcoming economic thunderstorm, the spiral of recession, the increase in unemployment, the brutal reduction of wages and pensions, the further fall of GDP and the increase of the debt. The always renewed fatal economic forecasts, simply postpone the explosion of the deadlock. Basic economics in theory and in practice are being depreciated (Negreponti-Delivani, 2014). One wonders if there is any serious economist, neoliberal, not to mention, Keynesian and/or radical that, may support the possibility of an economic recovery under deep recession policies and the existence of a hard currency such as the euro. So far as we know, there is no such a case in real life, anytime, anywhere. Trapped under Berlin's political prison and the euro zone fetish, Greece continuous to follow its tragic road on the grounds that there is no alternative. Yet, in democracies there are no dead ends. If an economic policy is proven to be wrong and/or catastrophic, the best alternative is to change it.

Table 2. World Bank Forecasts for Annual Growth of the GDP in selected areas and countries

\begin{tabular}{|c|c|c|c|}
\hline & $2015 f$ & $2016 \mathrm{f}$ & 2017 \\
\hline \multicolumn{4}{|l|}{ REAL GDP1 } \\
\hline World & 2.8 & 3.3 & 3.2 \\
\hline High income & 2.0 & 2.4 & 2.2 \\
\hline United States & 2.7 & 2.8 & 2.4 \\
\hline Euro Area & 1.5 & 1.8 & 1.69 \\
\hline Japan & 1.1 & 1.7 & 1.2 \\
\hline
\end{tabular}

\footnotetext{
${ }^{9}$ The European Commission, in av official statement by the end of October 2015, foresee that, in the euro zone area, the GDP growth will be $1,6 \%$ in $2015,1,8 \%$ in 2016 and 1,9\% in 2017. For Greece, according to the E.C. there will be a decline of the GDP at a level of $-1,4$ in 2015 and of $-1,3 \%$ in 2016 . The Greek government in its budget draft for the year 2016, predicts a GDP decline of $-2,3 \%$ for 2015 and of $-1,3 \%$ for 2016 .
} 


$\begin{array}{lccc}\text { United Kingdom } & 2.6 & 2.6 & 2.2 \\ \text { Russia } & -2.7 & 0.7 & 2.5 \\ \begin{array}{l}\text { Developing } \\ \text { countries }\end{array} & 4.4 & 5.2 & 5.4 \\ \begin{array}{l}\text { East Asia } \\ \text { Pacific }\end{array} & 6.7 & 6.7 & 6.6 \\ \text { China } & 7.1 & 7.0 & 6.9\end{array}$

Histogram 7. Working hours around the world

Total hours per worker (2013)

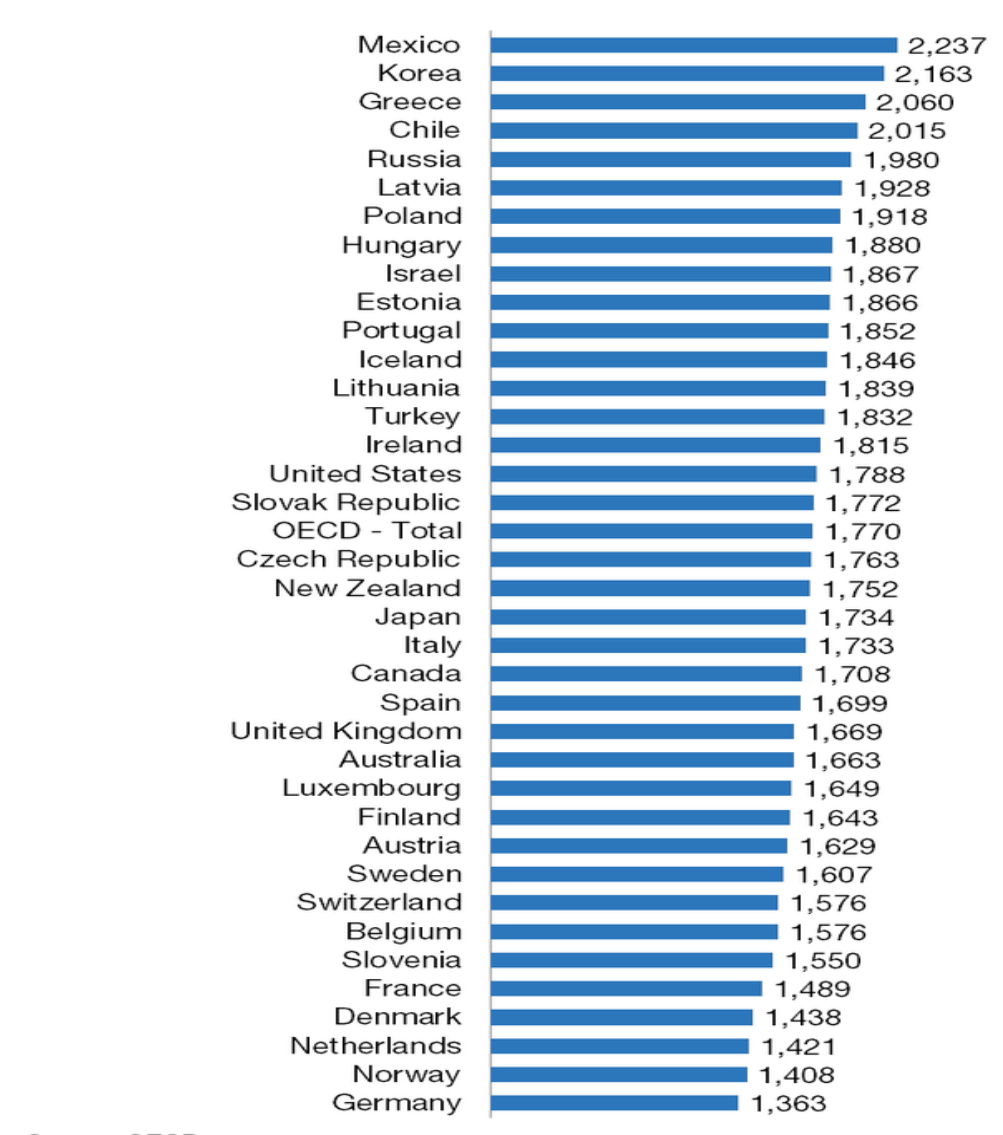

Source: OECD

\section{The friendly Grexit as the best alternative}

As things stand today and given the present international geopolitical balance, the friendly Grexit, temporary or permanent, is the proper alternative for Greece. This 
implies a controlled bankruptcy, suspension of debt payments and negotiations for cutting and extending its repayment period. During the initial negotiation days, the government must be ready to provide liquidity to the economy through the issuing of non-interest state bonds at a ratio of 1: 1 in relation to the euro. Existing capital controls imposed by the euro zone and the recent widespread transactions with electronic money through the banks, could be used properly. By possessing the necessary domestic currency liquidity, the Greek government will be in a better negotiation position for the friendly Grexit, the necessary cut of the debt and the extension of its repayment period.

The next step will be the issuing of the new drachma devaluated at 25-30\% in relation to the euro, as a necessary precondition for regaining the lost competitiveness of the economy. In order to avoid the dangers of hyperinflation, the amount of new drachma produced, must not exceed a certain level of the $\mathrm{M} 2^{10}$. The euro may continue to be used as a parallel currency for a period decided in accordance with the result of negotiations and economic trends. The necessary imports for fuels and raw materials can be initially immunized by existing foreign reserves and transnational agreements and soon, with the strong inflow of foreign exchange from the expected increase in exports and tourism. In any case, the widespread fears for an initial vacuum of imported necessary goods does not exist, since at present, the total balance of payments for goods and services has shown a surplus of 1,8 billion euro in the year 2013 (The Minister of The Bank of Greece Report, 2014, page 115 ). Capital controls could contribute to improving the balance of payments, since through them it is possible to facilitate exports and reduce imports of non-essential luxury goods. The black economy and illegal work will be limited necessarily. Only legal immigrants could export a certain amount of taxpayer exchange and this alone, will prevent the inflow of excess number of economic immigrants without legal residence and work permit.

Internal economic transactions may supported by the issuing of the national currency. In the same way, the banks may be re-capitalised and provide the desperately needed liquidity to the economy. Low and medium incomes may be increased gradually, following labour productivity and GDP growth trends. Government spending restrictions, the combat of corruption, impunity, bureaucracy, tax evasion and the strengthening of productive investments, are also necessary. The Greek economy must be cleared from the pathetic syndrome of the "import country" that depends upon loans, reactivate its production basis, try to consume no more than

10 The M2 is briefly defined as the measure of money supply that includes cash and checking deposits (M1) as well as near money. "Near money" in M2, includes savings deposits, money market mutual funds and other time deposits, which are less liquid and not as suitable as exchange mediums but can be quickly converted into cash or checking deposits. 
it produces, abolish malpractices of the past and make a healthy new beginning towards the future.

\section{Epilogue}

The friendly Grexit, temporary or permanent, is attacked by several politicians, activists and analysts in Greece on the grounds that, it is proposed by our big "enemy", the German Minister of economics Wolfgang Schäuble. These attacks are made without examining the fact that, the proposal is made by the Berlin government for reasons beyond Greece. According to the same proposal, which is certainly negotiable for improvements, with a friendly temporary and/or permanent Grexit, the country will be endowed with 50 million euro and the drachma will be guaranteed by the European Central Bank. In this case, Greece will not be subject to the strict rules of the euro zone and it may pursue a targeted growth policy with the adoption of the national currency. The present German government for its own reasons related to the needs of strengthening the euro in international markets against the USA dollar, will not go away from its present harsh position regarding Greece as member of the euro zone. If the strict euro zone rules will be relaxed for Greece, then the same will be happen as a domino for other countries, resulting in the collapse of the Berlin's policy. If you want the 'euro at any price ", you will suffer all the sacrifices imposed by the rules of the euro zone, the Berlin says.

At present, in the days of the Modern Greek Tragedy, we must leave behind the obsessions, the hook, the absurdity of the "euro at all costs" that goes hand in hand with the barbaric Memorandum. After learning the lessons from our mistakes of the past, the stubborn insistence of being a member of the euro zone deadlock is a fatal illusion. Nor is there any solution by the ultra left "all or nothing" obsessions which shift the termination of the Greek tragedy in infinite future. The friendly Grexit must and will come sooner or later.

\section{References}

Alesina, A. \& R. Barro. (2002). Currency unions. Quarterly Journal of Economics 117 (2): 409-436.

Athanasiadis, J.A. (2013). The possibility of Hellenic exit from the eurozone. The plan B. Erasmus University, Rotterdam.

Bevan J. (2012). "Everything you wanted to know about the Greek bailout", http://www.room151.co.uk/blogs

Blanchard, O. (2015). Greece: Past critiques and the path forward.IMF.

Bootle R. (2012). "Leaving the Euro: a Practical Guide", Capital Economics, A submission for the Wolfson Economics Prize MMXII.

Buis, R. and Duval, R. (2011). Raising potential growth after the crisis: A quantitative assessment of the potential gains from structural reforms in the OECD area and beyond. OECD Economic Dept., Working paper No 35.

Chionis, D. (2015). Reform and growth or growth and reform. ICABE, 12-13 November

Darvas, Z. (2015). Is Greece destined to grow? Bruegel, June. 
Cohen, M. (2011). Argentina's economic growth and recovery. Routledge.

Deo S., Donovan P. \& Hatheway L. (2011). "A brief history of breakups”, UBS investment research.

Grauwe P. (2010). How to embed the Eurozone in a political union, VOX, LSE research.

Henkel Hans-Olaf, (Jun., 2011). It's time for the Nordeuro: when the Eurozone gets split in two. Die Welt, http://www.worldcrunch.com

International Monetetary Fund, (2013). "Greece: Ex Post Evaluation of Exceptional Access under the 2010 Stand-By Arrangement".

Issing, O. (2011). Moment of truth postponed. London: Office of Monetary and Financial Institutions Forum.

Jonung, L., Drea, E. (2009). The Euro: It can't happen. It's a bad idea. It won't work. US economists on the EMU, 1989-2002. Economic Papers.

Katsanevas, Th. (2014). Greece and the Eurozone Crisis. ICABE, www.icabe.gr

Katsanevas, Th. (2014). The transition to the dracma. Fotoyinica.

Katsanevas, Th. (2013). The modern Greek tragedy. E.I.R, The Sciller Institute.

Katsinos, A., Mariolis, T. (2012). Switch to devalued drachma and cost-push inflation:A simple input-output approach to the Greek case," Modern Economy, Vol. 3 No. 2, , pp. 164-170.

Keen, S. (2012). Debuking economics. The naked emperor dethroned. Zed Books.

Klein N. (2009). The shock doctrine: the rise of disaster capitalism. Metropolitan Books.

Kouretas G., Vlamis P. (2010). The Greek Crisis: Causes and implications. Panoeconomicus, 4, pp. 391-404.

Krauss, M. (2011). The eurozone north needs the south. N.Y.Times.

Krugman, P. (2012). Greece as a Victim" The New York Times.

Krugman P. (2012). End this depression now. Melrose Road Partners.

Lachman, D. (2011). Can the euro survive? London: Legatum Institute.

Landon, T. (2012). Whispers of return to drachma grow louder in Greek crisis. The New York Times.

Lapavitsas C., Kaltenbrunner A., Lambrinidis G., et al., (2010). The Eurozone between austerity and default. Research on Money and Finance occasional report.

LaRouche, L. (2000). Now, are you ready to learn about economics? The Schiller Institute.Washington, D.C.: EIR.

Liapis, K., Rovolis, A., Galanos, C. and Thalassinos, I.E. (2013). The Clusters of Economic Similarities between EU Countries: A View Under Recent Financial and Debt Crisis. European Research Studies Journal, 16(1), 41-66.

Mariolis, Th. (2013). Currency devaluation,external finance and economic growth, in Social Cohesion and Development.

Ministry of Economics of Greece, Budget Draft (2016).

Mundell, R. (1961). A theory of optimum currency areas. American Economic Review

Negreponti-Delivani, M. (2014). The killing of Greece. Ianos and L' Harmattan.

Okun, A.M. (1962). Potential GNP, its measurement and significance. Yale University.

O Rourke, K.H. (2014). Wither the euro? Finance and Development, Vol 51.

Richards, J. (2012). Currency wars. The making of the next global crisis. Amazon.

Roggof, K., Reinchart, C. (2009). The time is different: Eight centuries of financial folly.Princeton University Press.

Rodrik, D. (2013). Economic rules : the rights and wrongs of the dismal science. Norton.

Rodrik, D. (2015). Structural reforms and Greece: Lessons from other countries. Athens, Oct. www.inerpost.gr 
Rousself Dilma (2011). Brazil will fight back against the currency manipulators. The Financial Times.

Saratrin, Odile, T. (2012). Europe does not need euro. Focus.

Sinn H.W. (2013). Greece should exit the Eurozone as soon as possible and be offered a return ticket. Open Europe, http://klauskastner.blogspot.gr/

Skarperdas, S. (2011). Seven myths about the Greek deb crisis. www.socsci.uci.edu/skarpedasmythsWP1011

Spiegel P., Harding R. (2013). IMF admits to errors in international bailout of Greece. Financial Times, http://www.ft.com/intl/cms

Summers, R., Heston, A. (1991). The Penn World Tables ( Mark5) : An expanded set of international comparisons 1950-1988.Quartely Journal of Economics 106 (2).

Tepper J. (2013). The end of the debt supercycle and how it changes. Endgame.

Thalassinos, I.E., Ugurlu, E. and Muratoglu, Y. (2012). Income Inequality and Inflation in the EU. European Research Studies Journal, 15(1), 127-140.

Thalassinos, E.P. (2014). Credit Default Swaps and Sovereign Debt in Eurozone. Chapter book in, Risk Management: Strategies for Economic Development and Challenges in the Financial System,(eds), D. Milos Sprcic, Nova Publishers, 255-278, ISBN: 978163321539-9; 978-163321496-5.

Thalassinos, I.E., Liapis, K. and Thalassinos, E.J. (2014). The role of the rating companies in the recent financial crisis in the Balkan and black sea area. Chapter book in Economic Crisis in Europe and the Balkans, 79-115, Contributions to Economics, Springer International Publishing, DOI: 10.1007/978-3-319-00494-5-6.

Thalassinos I.E. and Liapis K. (2014). Segmental financial reporting and the internationalization of the banking sector. Chapter book in, Risk Management: Strategies for Economic Development and Challenges in the Financial System,(eds), D. Milos Sprcic, Nova Publishers, 221-255, ISBN: 978-163321539-9; 978-163321496-5.

Thalassinos, I.E., Th. Stamatopoulos, D.T. and Thalassinos, E.P. (2015). The European Sovereign Debt Crisis and the Role of Credit Swaps. Chapter book in The WSPC Handbook of Futures Markets (eds) W. T. Ziemba and A.G. Malliaris, in memory of Late Milton Miller (Nobel 1990) World Scientific Handbook in Financial Economic Series Vol. 5, Chapter 20.

The Minister of The Bank of Greece Report, (2014).

Van Overtveldt J. (2012). The end of the Euro: the uneasy future of the European Union. Amazon.

Volcker, P., Gyohten, T. (1993). Changing fortunes. The world's money and the threat to American leadership. Amazon.

Weeks, J. (2013) Join the euro? Yes, for lower growth.www.socialeurope.eu http://www.socialeurope.eu/2013/08/join-the-euro-yes-for-lower-growth/ 